\title{
Raphanus sativus (Radish): Their Chemistry and Biology
}

\author{
Rosa Martha Pérez Gutiérrez* and Rosalinda Lule Perez \\ Laboratorio de Investigación de Productos Naturales, Escuela Superior de Ingeniería \\ Química e Industrias extractivas IPN, México D.F. \\ E-mail: rmpg@prodigy.net.mx
}

Received January 22, 2004; Revised August 14, 2004; Accepted August 18, 2004; Published September 13, 2004

Leaves and roots of Raphanus sativus have been used in various parts of the world to treat cancer and as antimicrobial and antiviral agents. The phytochemistry and pharmacology of this radish is reviewed. The structures of the compounds isolated and identified are listed and aspects of their chemistry and pharmacology are discussed. The compounds are grouped according to structural classes.

KEYWORDS: Raphanus sativus, Cruciferae, alkaloids, proteins, polysaccharides, phenolic and sulfur compounds

DOMAINS: pharmaceutical sciences, therapeutic drug modeling

\section{INTRODUCTION}

The plant family of Cruciferae contains many important vegetables of economic importance. Raphanus sativus L. is originally from Europe and Asia. It grows in temperate climates at altitudes between 190 and $1240 \mathrm{~m}$. It is 30-90 cm high and its roots are thick and of various sizes, forms, and colors (see Fig. 1). They are edible with a pungent taste. Salted radish roots (Takuan), which are consumed in the amount of about 500,000 tons/year in Japan, are essentially one of the traditional Japanese foods. The salted radish roots have a characteristic yellow color, which generates during storage.

This specie is used popularly to treat liver and respiratory illnesses[1]. The antibiotic activity of its extracts and its time persistence validates its effectiveness in microbial sickness as reported in traditional medicine. The root's juice showed antimicrobial activity against Bacillus subtilis, Pseudomonas aeruginosa, and Salmonella thyphosa. The ethanolic and aqueous extracts showed activity against Streptococcus mutans and Candida albicans. Aqueous extract of the whole plant presents activity against Sarcinia lutea and Staphylococcus epidermidis[2]. Aqueous extract of the leaves showed antiviral effect against influenza virus. Aqueous extract of the roots showed antimutagenic activity against Salmonella typhimurium TA98 and TA100. In this review, the metabolites produced by $R$. sativus are presented according to structural classes. (See also Tables 1 through 10 at the end of this paper.) 


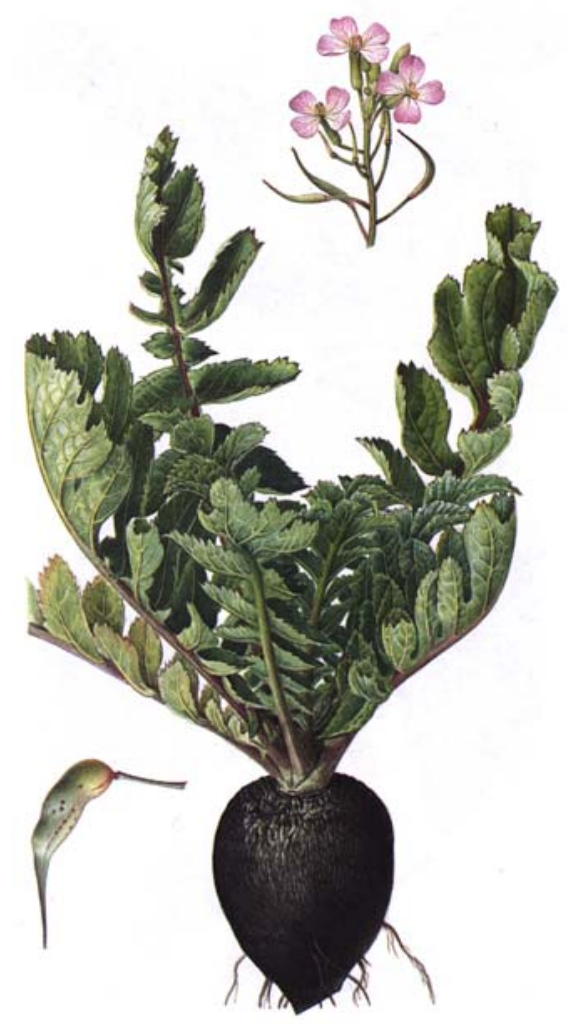

FIGURE 1

\section{CHEMICAL CONSTITUENTS}

\section{Alkaloids and Nitrogen Compounds}

Alkaloid and nitrogen compounds present in the roots were pyrrolidine, phenethylamine, $\mathrm{N}$ methylphenethylamine, 1,2'-pyrrolidin-tion-3-il-3-acid-carboxilic-1,2,3,4-tetrahydro- $\beta$-carboline, and sinapine[3,4,5]. Cytokinin (6-benzylamino-9-glucosylpurine) is a major metabolite of 6benzylaminopurine (6-BAP) in the root radish. A minor metabolite of 6-BAP from radish has been identified as 6-benzylamino-3- $\beta$-D-glucopyranosylpurine[6]. Total amino acids were $0.5 \%$ of dry wt; with proline $(0.5 \%)$ as the major constituent, methionine and cystine were present in traces $(0.02 \%)$. Diamines as diaminotoluene (2,4-D), 4,4'-methylenedianiline (4,4-D), and 1,6-hexanediamine (1,6-D) were isolated in the period of germination of young radish seeds. Production of thiamine is higher during germination radishes[7].

Total protein was 6.5\%[8]. Two chitinases, designated RRC-A and RRC-B, were isolated from radish roots. Both compounds had a molecular weight of $25 \mathrm{kDa}[9]$. N-Bromosuccinimide and di-Etpyrocarbonate inhibited the activities of both chitinases.

Arabinogalactan proteins (AGPs) were isolated from primary and mature roots of the radish. These were composed mainly of L-arabinose and D-galactose. Structures of the carbohydrate moieties of the root were essentially similar to those isolated from seeds and mature leaves in that they consisted of consecutive $(1 \rightarrow 3)$-linked $\beta$-D-galactosyl backbone chains having side chains $(1 \rightarrow 6)$-linked $\beta$-Dgalactosyl residues, to which $\alpha$-L-arabinofuranosyl residues were attached in the outer regions. One prominent feature of the primary root AGPs was that they contained appreciable amounts of L-fucose[10]. 
Two L-arabino-D-galactan-contained glycoproteins were isolated from the saline extract of mature radish leaves; both contained L-arabinose, D-galactose, L-fucose-4-O-methyl-D-glucuronic acid, and Dglucuronic acid residues. Degradation of the glycoconjugates showed that a large proportion of the polysaccharide chains is conjugated with the polypeptide backbone through a 3-O-D-galactosylserine linkage[11].

Arabino-3,6-galactan associated with a hydroxyproline-rich protein portion and carried a unique sugar residue, $\alpha$-L-fucopyranosyl-(1-2)- $\alpha$-L-arabinofuranosyl[12].

Stigma glycoproteins heritable with S-alleles (S-glycoproteins) were detected in $R$. sativus. Two main glycoproteins appeared on the SDS-gel electrophoretic pattern. Their molecular weights were established to be 15,000 and 100,000 Da. The carbohydrate fraction of the glycoprotein consisted of arabinose $17.3 \%$, galactose $19.1 \%$, xylose $8.1 \%$, mannose $5.4 \%$, glucose $23.7 \%$, and rhamnose or fucose $26.4 \%$. In the stigma surface diffusate of $R$. sativus, the content of protein was established to be $16 \%$ and that of carbohydrate was $11 \%[13]$.

The $R$. sativus acanthiformis showed two ferredoxin isoproteins indicating that plants have multiple genes for ferredoxin. The relative abundance of the isoproteins varied with leaf stage[14]. In the isoprotein isolated from roots of the radish, the amino acid composition and $\mathrm{N}$-terminal sequence were different from those of radish leaf ferredoxin.

Polypeptides RCA1, RCA2, and RCA3 were purified from seeds of $R$. sativus. Deduced amino acid sequences of RCA1, RCA2, and RCA3 have agreement with average molecular masses from electrospray mass spectrometry of 4537,4543 , and $4532 \mathrm{kDa}$, respectively. The only sites for serine phosphorylation are near or at the $C$ terminal and hence adjacent to the sites of proteolytic precursor cleavage[15].

Cysteine-rich peptides (Rs-AFP1 and Rs-AFP2) isolated from $R$. sativus showed peptides 6, 7, 8, and 9 comprising the region from cysteine 27 to cysteine 47[16]. Protein AFP1 isolated from radish showed peptide fragments (6-mer, 9-mer, 12-mer, and 15-mer)[17].

Proteins RAP-1 and RAP-2 were isolated from Korean radish seeds. The molecular mass of the two purified was established to be $6.1 \mathrm{kDa}$ (RAP-1) and $6.2 \mathrm{kDa}$ (RAP-2) by SDS-PAGE and $5.8 \mathrm{kDa}$ (RAP1) and 6.2kDa (RP-2) by gel filtration chromatography[17].

\section{Coumarins}

Hydroxycoumarins aesculetin and scopoletin were also identified[18].

\section{Enzymes}

A number of enzymes are present in both the cytoplasm and the cell wall, and in some cases it has been shown that the cell wall isozymes differ from those of the cytoplasmic[19]. When radish seedlings are grown in the dark, $\beta$-fructosidase $(\beta F)$ first accumulates in the cytoplasm, then slowly increases in the cell wall. Charge heterogeneity of cytoplasmic enzymes resides in the polypeptides, while the formation of the basic cell wall occurs as a result of post-translational modifications that can be inhibited by tunicamycin[20].

Cysteine synthase (EC 4.2.99.8) was purified to near homogeneity (275-fold) in $11.5 \%$ yield from mature roots. It was relatively stable, retaining most of its activity in standing for several days at room temperature[21].

A basic $\beta$-galactosidase ( $\beta$-Galase) has been purified from imbibed radish. This enzyme, consisting of a single polypeptide with an apparent molecular mass of $45 \mathrm{kDa}$ and $\mathrm{pI}$ values of 8.6 to 8.8, was maximally active at $\mathrm{pH} 4.0$ on p-nitrophenyl $\beta$-D-galactoside and $\beta$-1,3-linked galactobiose. Radish seed and leaf arabino-3,6-galactan-proteins were resistant to the $\beta$-Galase[22]. $\beta$-Amylase[23], together with peroxidase c or paraperoxidase[24], which is an isoenzyme, were also isolated from Japanese radish roots. 
A hydroxycinnamoyltransferase (EC 2.3.1.-), which catalyzes in vivo the formation of 1,2-di-Osinapoyl- $\beta$-D-glucose, was isolated from the radish. Cotyledons exhibited activities of 1-O-acyl-glucosedependent acyltransferases, 1-sinapoyl-glucose:L-malate sinapoyltransferase (SMT), and 1(hydroxycinnamoyl)-glucose:1-(hydroxycinnamoyl)glucose-hydroxyl cinnamoyl-transferase (CGT), showing contrary developments depending on light conditions. Light-grown seedlings showed high Lmalate sinapoyltransferase and low 1-(hydroxycinnamoyl)glucose-hydroxyl cinnamoyl-transferase activities, while dark-grown seedlings showed low L-malate sinapoyltransferase and high 1(hydroxycinnamoyl)glucose-hydroxyl cinnamoyl-transferase activities[25].

Catalase and glutathione reductase activities increased considerably in the root and leaves after 24-h exposure to cadmium, indicating a direct correlation with Cd accumulation. PAGE enzyme activity staining revealed several superoxide dismutase isoenzymes in leaves. The main response may be via activation of ascorbate-glutathione cycle for removal of hydrogen peroxide or to ensure availability of glutathione for synthesis of Cd-binding proteins[26].

A $\gamma$-glutamyl transpeptidase was found. It catalyzed the release of CySH-Gly from glutathione, the release of alanine from $\gamma$-glu-Ala, and the formation of $\gamma$-glutamyl dipeptides. A dipeptide formed from Smethylcysteine and glutathione or $\gamma$-glu-Ala was characterized as $\gamma$-glutamyl-S-methylcysteine[27].

Two cationic isoperoxidases (C1 and C3) and four anionic isoperoxidases (A1, A2, A3n, and A3) were isolated from Korean $R$. sativus L. root. All the six isoperoxidases are glycoproteins composed of a single polypeptide chain. The molecular weights of C1, C3, A1, and A2 were ca. 44,000, while anionic isoperoxidase A3n and A3 have molecular weights of 31,000 and 50,000, respectively. $\mathrm{N}$-terminal amino acid sequences were determined for A1, A3n, and C3, while A2 was found to have a blocked terminal residue[28]. Analysis of digested products of the two major N-glycans of C3 suggested that corefucosylated trimannosylchitobiose may contain a different linkage from the typical $\alpha-1,6$ of native $\mathrm{N}$ linked oligosaccharide[29].

Thiamin-binding substances were found in the radish. There were two kinds of compounds; one was heat labile and Pronase sensitive, and the other was heat stable and Pronase resistant. It would be inferred that the former is protein and the latter is a nonprotein compound[30].

$\beta \mathrm{F}$ is an isozyme (glycoprotein) found in the cytoplasm and cell walls of the radish. The nonglycosylated cytoplasmic and cell wall $\beta \mathrm{F}$ forms have the same relative molecular mass, but glycosylated forms have different oligosaccharide side chains with respect to size and susceptibility to $\alpha$ mannosidase and endoglycosidase D digestion[31].

7-Glucoside de zeatin, isolated from radish cotyledons, occurs naturally as glycoside with $\beta$-glucose as substituent. A large number of derivatives of purine are glucosylated, but adenine derivatives with alkyl side chains at least three carbon atoms in length at position N6 are preferentially glucosylated[20].

\section{Gibberellins}

The bolting (stem elongation accompanying flowering) of R. sativus L. cv. Taibyo-sobutori requires cold treatment (Vernalization) and subsequent long-day conditions. It has been suggested that gibberellins (GAs) might be involved in the control of bolting. Eleven gibberellins were identified in extracts of mature seed as 13 hydroxy-GAs [GA 1 , 3-epi-GA $, \mathrm{GA}_{8}, \mathrm{GA}_{17}, \mathrm{GA}_{19}, \mathrm{GA}_{20}$, and a new GA, 12 $\alpha$-hydroxy$\mathrm{GA}_{20}\left(\mathrm{GA}_{77}\right)$ ] and four non-13-hydroxy-GAs [GA9, GA $24,12 \beta$-hydroxy-GA $\left.{ }_{24}, \mathrm{GA}_{25}\right]$. The major GAs were $\mathrm{GA}_{8}, \mathrm{GA}_{20}$, and $\mathrm{GA}_{77}[32]$.

\section{Glucosinolates}

Glucosinolates are very stable water-soluble precursors of isothiocyanates. The relatively nonreactive glucosinolates are converted to isothiocyanates on wounding of the radish. The tissue damage releases 
myrosinase (EC 3.2.3.1), a glycoprotein that is physically segregated from its glucosinolate substrates. Large variations in myrosinase-specific activity have been reported in various Cruciferous plant sources. Myrosinase, purified to homogeneity from daikon, has a specific activity of $280 \mu \mathrm{Mol} / \mathrm{min} / \mathrm{mg}$ protein with sinigrin as a substrate[33]. Glucosinolate contents of seed of radish cultivar ranged from 37-87 $\mu \mathrm{mol} / \mathrm{g}$ seed. The 5-vinyl-2-oxazolidinethione, 3-butenyl, 4-pentenyl, and phenethyl isothiocyanate were found in industrially extracted rapeseed oils. The compounds were hydrolysis products from glucosinolates present in the seed[34].

Desulfoglucosinolates are formed by enzyme desulfation of endogenous glucosilates. The indole glucosinolates, 4-methoxy-3-indolylmethyl glucosinolate and 1-methoxy-3-indolylmethoxy glucosinolate, were absent in seed whereas 4-hydroxy-3-indolymethyl glucosinolate was found in highest concentration in the seeds. The 3-indolymethyl glucosinolate was found in low levels in seed, but was the dominant indole glucosinolate in the leaf[35].

\section{Oil Seed Components}

The seeds of the radish contain a high percentage of oil. Chromatographic analysis of these oils showed clearly their complete similarities to cottonseed oil[36]. The steam volatile constituents of fresh radish of Japanese and Kenyan origin have been studied. The overall pattern of compounds in the two materials was similar. Major components are pentyl hexyl, 4-methylpentyl isothiocyanate, dimethyl disulfide, methyl methanethiolsulfinate, and 1-methylthio-3-pentanone[37]. Oil radish seeds contained $1.21 \mu \mathrm{mol}$ of total alkenylglucosinolates (AG/g), consisting mostly of progoitrin and gluconapin[38].

\section{Organic Acids}

Four major organic acids are present in the roots of the radish: oxalic, malic, malonic, and erythorbic acid. Lipid total was 1.23\%[8]. Major fatty acids in seed lipids were erucic, oleic, linoleic, and linolenic acids. Major fatty acids in radish family lipids were linolenic acid (52-55\%), followed by erucic acid (30-33\%), and palmitic acid (20-22\%)[39]. Also identified were stearic acid from petroleum ether extracted from powdered $R$. sativus seeds. Glutamic acid is found in pickled daikon (20-100 mg\%)[40].

\section{Phenolic Compounds}

The content of phenolic acids in the roots of the radish were much smaller than in the leaves. Radishes and horseradish showed caffeic, $p$-coumaric, ferulic, hydroxycinnamic, p-hydroxybenzoic, vanillic, salicylic, and gentisic acid[18]. Sinapic acid esters (1-sinapolyglucose, sinapoyl-L-malate, and 6,3'disinapoylsucrose), kaempferol glycosides, and free malic acid were isolated from cotyledons of $R$. sativus seedlings[41].

Among the anthocyanins, pelargonidine and cyanidine were responsible for red and violet color in corollas and roots in all inbred progenies. The absence of pelargonidine and cyanidine resulted in a white color. The flavonoid, quercetine, was also found in both corolla and root[42]. Anthocyanins extracted from epidermal tissue resulted in juices with fairly low initial ${ }^{\circ}$ Brix $\left(1.3^{\circ}\right)$, containing $400 \mathrm{mg}$ anthocyanin $/ 100 \mathrm{ml}$. This compound provided color similar to FD\&C Red\#40. Radish concentrate extract represents a promising natural alternative to the use of FD\&C Red\#40[43].

Other purple root pigment isolated from progeny radish was an ester of cyaniding triglucoside and three kinds of cinnamic acids. The triglucoside was identified as the 2-diglucoside-5-monoglucoside of cyaniding (Rubrobrassicin)[44]. Other anthocyanins obtained from red radish are two diacylated pelargonidin 3-O-[2O- $\beta$-glucopyranosyl)-6-O-(trans-p-coumaroyl)- $\beta$-glucopyranoside]-5-O-(6-O-malonyl- $\beta$-glucopyranoside) and pelargonidin 3-O-[2-O-( $\beta$-glucopyranosyl)-6-O-(trans-p-feruloyl)- $\beta$-glucopyranoside]-5-O-(6-O- 
malonyl- $\beta$-glucopyranoside) and other monoacylated anthocyanins pelargonidin 3-O-[2-O- $\beta$ glucopyranosyl)-6-O-(trans-p-coumaroyl)- $\beta$-D-glucopyranoside]-5-O-( $\beta$-glucopyranoside) and pelargonidin 3-O-[2-O- $\beta$-glucopyranosidel)-6-O-(trans-p-feruloyl)- $\beta$-glucopyranoside]-5-O-( $\beta$-glucopyranoside). Pelargonidin-3-diglucosido-5-monoglucoside is known as raphanusin[45].

The major anthocyanins of radishes are pelargonidin-3-sophoroside-5-glucoside acetylated with malonic acid and either ferulic or p-coumaric acid. Cinnamic acid acylation site for radish anthocyanins was determined to be at position 6 of glucose- 1 of the sophorose substituents by one- and twodimensional ${ }^{1} \mathrm{HNMR}-{ }^{13} \mathrm{CNMR}[46]$. Also 7-glucoside-pelargonidin has been identified in $R$. sativus[47]. This compound was stable at $60^{\circ} \mathrm{C}$ and under light, may be used as a food colorant[48].

Kaempferol-7-O-rhamnoside, isorhamnetin-7-O-rhamnoside, quercetin-7-O-rhamnoside, kaempferol3-glucoside-7 rhamnoside, kaempferol-7-glucoside-3 rhamnoside, quercetin-7-O-arabinoside-3-glucoside, and quercetin-7-glucoside-3 rhamnoside were isolated from $R$. raphanistrum[49]. Radishes have a high content of flavonoids as quercetin, kaempferol, myricetin, apigenin, and luteolin[50]. Malvidin-3,5diglucoside was produced from the callus of radish via tissue cultivation. The callus contains $16.4 \%$ (dry wt) pigments[51].

\section{Pigments}

Salted radish roots have a characteristic yellow color, which generates during storage. 4-Methylthio-3butenyl-glucosinolate (4-MTBG) is the substrate of the main pungent principle of radish and is one of the essential factors for the formation of the yellow pigment. The yellow compound 1-(2'-pyrrolidinethion$3^{\prime}$-yl)-1,2,3,4-tetrahydro- $\beta$-carboline-3-carboxilic acid is presumed to have been the condensation product from the degradation of 4-methylthio-3-butenylisothiocyanate and L-tryptophan, which carboline compound is considered to play an important role in the formation of the yellow pigment in salted radish $\operatorname{roots}[52]$.

\section{Polysaccharides}

Pectic substances were extracted from the leaves with oxalate buffer of $\mathrm{pH} 4.25$ as weakly acidic pectic polysaccharide (WAP) and pectic acid. WAP was appreciably hydrolyzed by exo- and endopolygalacturonases and the galacturonic acid content (17.3-25.8\%) was much lower than the pectic acids, though the neutral sugar components of both pectic substances were almost the same. The arabinose-galactose side chains were very long or highly branched in pectine compared with those in pectic acids. These compounds are probably inherent pectic components of the cell walls of the vegetables[53]. Rhamnose, glucose, and xylose were also isolated. Lipopolysaccharides (LPS) were isolated from radish roots[54].

\section{Proteoglycan}

An L-arabino-D-galactan-contained proteoglycan was isolated from hot phosphate-buffered saline extract of radish seeds by ethanol fractionation. The proteoglycan consisted of $86 \%$ of a polysaccharide component-contained L-arabinose and D-galactose as major sugar constituents, together with small proportions of D-xylose, D-glucose, and uronic acids, and 9\% of a hydroxyproline-contained protein. Arabinogalactan from radish seed had a high content (81\%) of L-arabinose and its basic structure seemed to be similar to that of the polysaccharide component of the proteoglycan[55]. 


\section{Sulfur Compounds}

Radish leaves contain only one of the sulfonium diateroisomers of S-adenosylmethionine (AdoMet), which has a remarkable variety of biochemical functions. It is an allosteric enzyme effector and a precursor of spermine biosynthesis, spermidine, and ethylene. It is also the methyl group donor for most biological transmethylation reactions, wherein transfer of its methyl group converts AdoMet to the homocysteine analog (AdoHcy). Much of the chemistry and biochemistry of AdoMet derives from the fact that it is a sulfonium compound[56]. 1-(2'-Pyrrolidinethion-3'-yl)-1,2,3,4-tetrahydro- $\beta$-carboline-3carboxilic acid was found in radish root. This carboline compound is considered to play an important role in the formation of the yellow pigment in salted radish roots.

\section{Other Constituents}

$\beta$-Carotene was isolated from radish. Vitamin $C$ content in fresh hotbed radishes ranged from 17.95$27.86 \mathrm{mg} \%[57]$. Also identified was $\beta$-sitosterol from $R$. sativus seeds[40]. The contents of raphanusol A and $\mathrm{B}$ in radish increased at the lighted side and decreased in the shaded side. The differential distribution of raphanusol A and B in the hypocotyls is closed correlated with growth suppression at lighted side[58].

\section{BIOLOGICAL ACTIVITIES}

\section{Allergic Contact}

In the radish, the allyl isothiocyanate released enzymically from simigrin, a thioglycoside, was identified as a possible sensitizing substance. In some cases, it can produce allergic contact and dermatitis[59]. The leaves of this plant also contained glucoparin that produced allergic contact.

\section{Antimicrobial Activity}

Crude juice of the radish inhibited the growth of Escherichia coli, Pseudomonas pyocyaneus, Salmonella typhi, and Bacillus subtilis in vitro. This common plant may be an important source of antimicrobial substances[60]. The cysteine-rich peptides (Rs-AFP1 and Rs-AFP2) isolated from R. sativus showed substantial antifungal activity against several fungal species with minimal inhibitory concentration (MIC) of 30-60 $\mu \mathrm{g} / \mathrm{ml}$. Both Rs-AFPs are among the most potent antifungal proteins characterized. Moreover, their antibiotic activity shows a high degree of specificity to filamentous fungi[16]. The active region of the antifungal protein appears to involve $\beta$-strands 2 and 3 in combination with the loop connecting those strands[61]. Rs-AFP1 and Rs-AFP2 are highly basic oligomeric proteins composed of small (5-kDa) polypeptides that are rich in cysteine. These proteins are located in the cell wall and occur predominantly in the outer cell layers lining different seed organs. Moreover, Rs-AFPs are preferentially released during seed germination after disruption of the seed coat[62]. Two purified antifungal proteins RAP-1 and RAP2 isolated from Korean radish seeds ( $R$. sativus) exhibited growth-inhibitory activities against Candida albicans and Saccharomyces cerevisiae[63]. The protein AFP1 isolated from the radish showed antifungal activity against Fusarium culmorum[17].

Caffeic acid showed antifungal properties in vitro against Helminthosporium maydis. It has antibacterial, antifungical activities. Ferulic acid is active against Sytaphylococcus aureus, Bacillus subtilis, Corynebacterium, diphtheria, Aspergillus niger, and Candida albicans. These acids displayed antibacterial activity against Gram-positive bacteria Bacillus subtilis and Staphylococcus aureus, and the Gram-negative Escherichia coli and Kliebsiella pneumoniae. The MIC values were $1.56-3.13 \mu \mathrm{g} / \mathrm{ml}$. 
These $p$-hydroxybenzoic acid (hydroxycinnamic, $p$-hydroxybenzoic) showed marked activity against Gram-positive bacteria.

The inoculation of sliced daikon roots with the bacterium Pseudomonas cichorii induced the formation of several antifungal compounds including brassinin, methoxybrassinin, spirobrassinin, and 3indolecarbaldehydes[64].

The radish released biocidal compounds, mainly isothiocyanates, produced during the enzymic degradation of glucosinolates present in the plant cell. The highest fungicidal activity depended on concentration of isothiocyanates[65].

\section{Antioxidative Activity}

The red radish pigment (pelargodinin-3-sophoroside-5-glucoside) had almost the same antioxidative activity as BHT at the same concentration. The inhibition ratio could reach more than $93 \%$ by the $0.01 \%$ pigment addition[66]. Also, the caffeic acid showed antioxidative activity.

\section{Antitumor Activity}

A neutral fraction of kaiware radish extract aqueous in vitro showed proliferation inhibition of mouse embryo fribroblast 3T3 cells and papovavirus SV40 transformed 3T3 cells with $\mathrm{IC}_{50}$ of 17.4 and 8.7 $\mu \mathrm{g} / \mathrm{ml}[67]$. Diaminotoluene (2,4-D) showed highest cytotoxic activity against He-La cells, 4,4'methylenedianiline (4,4-D) intermediate, and 1,6-hexanediamine (1,6-D) lowest cytotoxicity. However, the phytotoxicity decreased in order of 4,4-D >2,4-D>1,6-D[7].

\section{Antiviral Activity}

Caffeic acid and pelargonidin are virucidal for several enveloped viruses[41]. The lipopolysaccharides showed antiherpes activity.

\section{Calmodulin Antagonists}

The polypeptides RCA1, RCA2, and RCA3 inhibit chicken gizzard calmodulin-dependent myosin light kinase assayed with a myosin-light chain-based synthetic peptide substrate[15].

\section{Growth Inhibitors}

The hypocotyls cis- and trans-raphanusanins and 6-methoxy-2,3,4,5-tetrahydro-1,3-oxazepin-2-one (raphanusamide) were isolated from radish. Cis- and trans-raphanusanins inhibited the hypocotyls growth at concentrations higher than $1.5 \mu \mathrm{M}$ and raphanusamide at concentrations higher than $20 \mu \mathrm{M}[68]$. Growth-inhibitor 2-thioxothiazolidine-4-carboxilic acid was isolated from acetone extract of lightexposed seedlings of Sakurajima radish. It inhibited the growth of hypocotyl sections of etiolated Sakurajima radish and intact hypocotyls of etiolated lettuce seedlings at concentrations greater than 3 $\mathrm{mg} / \mathrm{ml}$. Gibberellins were identified in extracts of mature seed radish and might be involved in the control of bolting (stem elongation accompanying flowering) of $R$. sativus[32]. 


\section{Hypotensive}

Sinapine was extracted with methanol. It is a hypotensive constituent of laifuzi (Semen raphani) and seed of $R$. sativus[5].

\section{Platelet Aggregation Inhibitor}

The 6-methyl-sulfinylhexyl-isothiocyanate (MS-ITC) was isolated from wasabi horseradish (Japanese domestic) as a potential inhibitor of human platelet aggregation in vitro. It is a potential inducer of GST (glutathione S-transferase). In the mechanism of MS-ITC, the isothiocyanate moiety of MS-ITC plays an important role for antiplatelet and anticancer activities because of its high reactivity with sulfhydryl (-SH) groups in biomols (GSH, cysteine, residue in a certain protein)[69].

\section{Immunological Properties}

The AGPs isolated from the radish showed immunological properties. Radish AGPs R-I, R-II, crude fraction R-C, and turnip AGP B-II reacted with eel anti-H serum, indicating that these AGPs shared common antigenic determinants[70]. The root's AGPs were composed mainly of L-arabinose and Dgalactose, but were distinguishable from each other in their contents of L-fucose as well as of protein and hydroxyproline. Structures of AGPs from the root, seeds, and mature leaves were essentially similar[71]. Proteoglycan from radish leaves and seeds appeared to share common antigenic determinant[55].

\section{Phytoalexins}

The inoculation of sliced daikon roots with the bacterium Pseudomonas cichorii induced the formation of several antifungal compounds including brassinin, methoxybrassinin, spirobrassinin, and 3indolecarbaldehydes[64].

\section{Pungent Principle}

The pungent principle extracted from the radish root is trans-4-methylthio-3-butenyl-isothiocyanate. Also isolated was the cis-isomeride, in a trans-cis ratio of 4:1[72]. 2-Thioxo-3-pyrrolidinecarbaldehyde (TPC) is a major product generated from the pungent principle of radish. This compound possesses antimicrobial activity with the MIC against fungi and bacteria ranging from $50-400 \mu \mathrm{g} / \mathrm{ml}$, while yeasts were more resistant. The antifungal and antibacterial actions were due to the sporicidal and bactericidal activities. A dose-dependent inhibition of the uptakes of both oxygen and the precursors for RNA and DNA was observed, suggesting that TPC caused damage to the mitochondrial functions and biosynthetic systems[73].

\section{Serological Activity}

AGPs were presumably responsible for expression of the serological activity. In their immunological reactions with rabbit antiradish leaf AGP antibody, the root AGPs were shown to share common antigen determinant with those of seed and leaf AGPs[10]. Arabino-3,6-galactan associated with a hydroxyproline-rich protein portion, which might be responsible for the serological H-like activity of the 
AGPs[12]. Two L-arabino-D-galactan-contained glycoproteins having potent inhibitory activity against eel anti-H agglutinin were isolated from the saline extract of mature radish leaves[70].

\section{Intestine Motility Stimulation}

The effect of radish aqueous extract at doses of $10 \mu \mathrm{g} / \mathrm{ml}$ to $2 \mathrm{mg} / \mathrm{ml}$ caused a dose-dependent increase in contractions of the duodenum, jejunum, and ileum. Ileal contraction was remarkably inhibited by pretreatment of atropine $\left(10^{-7} \mathrm{M}\right)$ by $10 \mathrm{~min}$. Oral administration of radish extract $(300-500 \mathrm{mg} / \mathrm{kg}$ body wt) to mice improved the intestinal transit of charcoal and this was significantly attenuated by coadministration of atropine $(50 \mathrm{mg} / \mathrm{kg})$. These results suggest that radish extract stimulates gastrointestinal motility through activation of muscarinic pathways[74]. Scopoletin is an antispasmodic agent.

\section{Cardiovascular Disease Prevention}

Radish powder decreased the lipid levels by increasing the fecal excretion of total lipids, triglycerides, and total cholesterol. Catalase and glutathione peroxidase (GSH-Px) activities in red blood cell (RBC) were most remarkably increased by radish. Superoxide dismutase (SOD), catalase, and GSH-Px activities in the liver were increased by radish powder. Xanthine oxidase (XOD) activities in the liver were decreased by radish. Flavonoids and vitamin $\mathrm{C}$ in radish may inhibit lipid peroxidation, promote liver and $\mathrm{RBC}$ catalase, and inhibit XOD activities in animals tissues. Radish can be recommended for the treatment and prevention of diseases such as cardiovascular disease and cancer and for delaying aging[75].

\section{Other Activities}

Lipopolysaccharides (LPS) were isolated from radish having a macrophage activating with $\mathrm{ED}_{50}$ of 0.4$100 \mathrm{ng} / \mathrm{ml}$. These compounds can be used as antidiabetic agents in pharmaceutical or veterinary fields. Also the LPS showed analgesic activity[54].

\section{REFERENCES}

1. Paredes, S.D. (1984) Etnobotánica Mexicana: Plantas popularmente empleadas en el Estado de Michocán en el tratamiento de enfermedades hepaticas y vesiculares. Tesis Lic. México D.F. Facultad de Ciencias. UNAM.

2. Caceres, A. (1987) Screening on antimicrobial activity of plants popular in Guatemala for the treatment of dermatomucosal diseases. J. Ethnopharm. 20, 223-237.

3. Marquardt, P. (1976) N-methylphenethylamine in vegetables. Arzneimittelforschung 26, 201-203.

4. Wan, C. (1984) Studies on chemical constituents in radish (Raphanus sativus L.) seeds. II. Shaanxi Xinyiyao 13, 5455.

5. Weilan, W., Jin, Z., Zhongda, L., and Meng, L. (1987) Hypotensive constituents of Laifuzi (Semen raphani). Zhongcaoyao 18, 101-103.

6. $\quad$ Coeley, D.E., Jenkins, I.D., MacLeod, J.K., Summons, R.E., Lethman, D.S., and Parker, C.W. (1975) Structure and synthesis of unusual cytokinin metabolites. Tetrahedron Lett. 1015-1918.

7. Mal-Nam, K., Ji-Chul, J., Ik-Mo, L., Han-Sup, L., and Jin-San, Y. (2002) Toxicity and biodegradation of diamines. J. Environ. Sci. Health B 37, 53-64.

8. Shyamala, G. and Singh, P.N. (1987) An analysis of chemical constituents of Raphanus sativus. Proc. Natl. Acad. Sci. India Sect. B 57, 157-159.

9. $\quad$ Chen-Tien, C., Sheng-Ting, C., Rong-Jen, S., Hsiu-Chiu, L., Li-Ling, C., and Hsien-Yi, S. (2000) Purification and properties of chitinases from radish roots. Food Sci. Agric. Chem. 2, 107-114.

10. Tsumuraya, Y., Ogura, K., Hashimoto, Y., Muroyama, H., and Yamamoto, S. (1988) Arabinogalactan-proteins from primary and mature roots of Radish (Raphanus sativus L.). Plant Physiol. 86, 155-160.

11. Yoichi, T., Yohichi, H., Shigeru, Y., and Naoto, S. (1984) Structure of L-arabino-D-galactan contained glycoproteins from radish leaves. Carbohydr. Res. 134, 215-218. 
12. Tsumuraya, Y., Nakamura, K., Hashimoto, Y., and Yamamoto, S. (1984) Immunological properties of arabinogalactan proteins from leaves of Cruciferous plants. Agric. Biol. Chem. 48, 2915-2917.

13. Yinghua, Z., Zhonghan, Y., and Zongxun, C. (1983) Studies on stigma pellicle glycoproteins of Raphanus sativus L. Zhiwu Xuebao 25, 544-550.

14. Keishiro, W., Oka, O., and Hirozo, M.H. (1985) Ferredoxin isoproteins and their variation during growth of higher plants. Physiol. Veg. 23, 679-686.

15. Polya, G.M., Chandra, S., and Condron, R. (1993) Purification and sequencing of radish seed calmodulin antagonists phosphorylated by calcium-dependent protein kinase. Plant Physiol. 101, 545-551.

16. Terras, F.R., Schoofs, H.M., DeBolle, M.F., Van Leuven, F., Rees, S.B., Vanderleyden, J., Cammue, B.P., and Broekaert, W.F. (1992) Analysis of two novel classes of plant antifungal proteins from Radish (Raphanus sativus L.) seeds. J. Biol. Chem. 267, 15301-15309.

17. Hans, M.R., Cornelis, P.W., Martinus, S.W., Lolke, S., Broekaert, W.F., Bronwen, R.S., Martinus, V.W. (1997). Antifungal protein fragment-derived peptides and their agricultural, therapeutic, or preservative uses. UK PCT. Appl. Wo 97 21,815 (cl. Cl2N15/29), 19 june 1997.

18. Stoehr, H. and Herrmann, K. (1975) Phenolic acids of vegetables. III. Hydroxycinnamic and hydroxybenzoic acids of root vegetables. Z. Lebensm. Unters. Forsch. 159, 219-224.

19. $\quad$ Matile, P. (1975) The Lytic Compartment of Plant Cells. Springer-Verlag, New York. pp. 56-63.

20. Faye, L., Mouatassim, B., and Ghorbel, A. (1986) Cell wall and cytoplasmic isozymes of radish- $\beta$-fructosidase have different N-linked oligosaccharides. Plant Physiol. 80, 27-23.

21. Tamura, G., Iwasawa, T., Masada, M., and Fukushima, K. (1976) Some properties of cysteine synthase from radish roots. Agric. Biol. Chem. 40, 637-638.

22. Sekimata, M., Ogura, K., Tsumuraya, Y., Hashimoto, Y., and Yamamoto, S. (1989) A $\beta$-galactosidase from radish (Raphanus sativus L.) seeds. Plant Physiol. 90, 567-574.

23. Shigeo, A. and Yuhei, M. (1976) $\beta$-Amylase of the Japanese radish and soybeans. Tampakushitsu Kakusan, Koso, Bessatsu 434-436.

24. Yuhei, M. (1973) Preliminary crystallographic data for a basic peroxidase from Japanese radish. Mem. Res. Inst. Food. Sci. Kyoto Univ. 36, 9-11.

25. Dahlbender, B. and Strack, D. (1986) Purification and properties of 1-(hydroxycinnamoyl)-glucose: 1(hydroxycinnamoyl)-glucose hydroxycinnamoyl- transferase from radish seedlings. Phytochemistry 25, $1043-1046$. Vitoria, A.P., Lea, P.J., and Azevedo, R.A. (2001) Antioxidant enzymes response to cadmium in radish tissue. Phytochemistry 57, 701-710.

27. Thompson, J.F., Turner, D.H., and Gering, R.K. (1964) $\gamma$-Glutamyl transpeptidase in plants. Phytochemistry 3, 33-46.

28. Lee, M.Y. and Kim, S.S. (1994) Characteristics of six isoperoxidases from Korean radish root. Phytochemistry 35, 287-290.

29. Kim, S.H. and Kim, S.S. (1996) Carbohydrate moieties of three radish peroxidases. Phytochemistry 42, $287-290$.

30. Toshio, M., Yoshiko, A., Atsuko, I., Mayumi, S., and Akio, I. (1984) Occurrence of thiamin-binding substances in plant foods. Nippon Eiyo, Shokuryo Gakkaishi 37, 139-143.

31. Loic, F., Bouchaib, M., and Abdelwahed, G. (1986) Cell wall and cytoplasmic isosymes of radish $\beta$-fructosidase have different N-linked oligosaccharides. Plant Physiol. 80, 27-33.

32. Nakayama, M., Yamane, H., Yokota, T., Yamaguchi, I., Murofushi, N., Takahashi, N., Nishijima, T., Katsura, N., Nonaka, M., Gaskin, P., MacMillan, J., Mander, L.N., and Cu, A. (1990) Endogenous gibberellins in mature seed of Raphanus sativus L. cv. Taibyo-sobutori. Agric. Biol. Chem. 54, 837-840.

33. Fahey, J.W., Zalcmann, A.T., and Talalay, P. (2001) The chemical diversity and distribution of glucosinolates and isothiocyanates among plants. Phytochemistry 56, 5-51.

Daun, J.K. and Hougen, F.W. (1977) Identification of sulfur compounds in rapeseed oil. J. Am. Oil. Chem. Soc. 54, 351-354.

35. Sang, J.P., Minchinton, I.R., Johnstone, P.K., and Truscott, R.J.W. (1984) Glucosinolate profiles in the seed, root and leaf tissue of cabbage, mustard, rapeseed, radish and swede. Can. J. Plant Sci. 64, 77-93.

36. El-Hinnawy, I., Barakat, S., and Fouad, K.R. (1975) Biochemical studies on some oleaginous seeds of Cruciferae plants. Grasas Aceites 26, 147-149.

37. Anders, K., Oegaard, J., Yasuhiko, M., Yoshio, O., and Yasushi, M. (1978) Volatiles in distillates of fresh radishes of Japanese and Kenyan origin. Agric. Biol. Chem. 42, 1715-1721.

38. Jaroslav, V. (1990). Content of alkenylglucosinolates in oil-bearing Cruciferae seeds. Rostl. Vyroba 36, $227-233$.

39. Seiichiro, N., Kenjiro, T., Ikuko, N., and Kayo, M. (1984) Lipids in vegetables. III. Variation of lipids and fatty acid composition in seed and growth stage of Chinese vegetable (part 2). Kenkyu Hokoku-Miyazaki Daigaku Nogakubu 31, 45-56.

40. $\quad$ Changdai, W. (1984) Studies on chemical constituents in Radish (Raphanus sativus L) Seed II. Shaanxi Xinyiyao 13, $54-55$.

41. Strack, D., Pieroth, M., Scharf, H., and Sharma, V. (1985) Tissue distribution of phenylpropanoid metabolism in cotyledons of Raphanus sativus L. Planta 164, 507-511.

42. Narbut, S.I., Samorodova, G.B., and Fedorov, V.S. (1972) Root and corolla color in the plants of varieties and inbred lines of radish. Vestn. Leningr. Univ. Biol. 2, 128-139. 
43. Rodriguez, S.L., Giusti, M.M., Durst, R.W., and Wrolstad, R.E. (2001) Development and process optimization of red radish concentrate extract as potential natural red colorant. J. Food Process. Preserv. 25, 165-182.

44. Isikura, N., Hoshi, T., and Hayashi, K. (1965) Anthocyanins. XLV. Crystallization and characterization of the basic triglucoside common to all components in purple pigment of hybrid radish. Bot. Mag. 78, 8-13.

45. Guisti, M.M., Ghanadan, H., and Wroslstad, R.E. (1998) Elucidation of the structure and conformation of red radish (Raphanus sativus) anthocyanins using one-and two dimensional nuclear magnetic resonance techniques. J. Agric. Food Chem. 46, 4858-4863.

46. Wrolstad, R.E., Giusti, M.M., Rodriguez, S.L., and Durst, R. (2001) Anthocyanins from radishes and red-fleshed potatoes. Symp. Ser. 775, 66-69.

47. Harborne, J.B. (1963) Flavonoid sophorosides. Experientia 19, 7-8.

48. Junlian, T., Qingjun, J., and Jiansheng, L. (1992) Extraction and stability of edible pigment from red heart radish. Ниахие Shijie 33, 114-117.

49. Kamil, K. and Kalina, K. (1977) Flavonoid heterosides in the herb of Raphanus raphanistrum L. Herba Pol. 23, 291293.

50. Lugasi, A. and Hovari, J. (2000) Flavonoid aglycons in foods of plant origin. I. Vegetables. Acta Aliment. 29, 345-352.

51. Kwan, H., Byong, K., Cho, H.L., Kyu, H. (1995). Preparation of anthocyanin-type red pigment via tissue cultivation of Raphanus sativus L. Repub. Korea KR 9,504772, (cl. Cl2P19/00), 10 may 1995.

52. Ozawa, Y., Kawakishi, S., Uda, Y., and Maeda, Y. (1990) Isolation and identification of a novel $\beta$-carboline derivative in salted radish roots, Raphanus sativus L. Agric. Biol. Chem. 54, 1241-1245.

53. Matsuura, Y. and Hatanaka, C. (1988) Weakly acidic pectic polysaccharides of Japanese Radish and cabbage. Agric. Biol. Chem. 52, 2583-2588.

54. Genichiro, S., Kiyoshi, Y., Daisuke, T., Denichi, M., and Haruyuki, O. (1991) Eur. Pat. Appl. EP. 462,022 (Cl. A61K37/20), 18 dec 1991, JP Appl. 90/155,428, 15 jun 1990.

55. Yoichi, T., Yoichi, H., and Shigeru, Y. (1987) An L-arabino-D-galactan and an L-arabino-D-galactan contained proteoglycan from radish (Raphanus sativus) seeds. Carbohydr. Res. 161, 113-126. Creason, G.L., Madison, J.T., and Thompson, J.F. (1985) Soybeans and radish leaves contain only one of the sulfonium diateroisomers of S-adenosylmethionine. Phytochemistry 24, 1151-1155.

57. Bulinski, R. and Zhinda, M. (1962) Vitamin C in radishes. Ann. Univ. Mariae Curie-Sklodowska 16, $433-439$.

58. Koji, H. and Shigenori, T. (1989) Phototropism in hypocotyls of radish. VII. Involvement of the growth inhibitors raphanusol A and R in phototropism of radish hypocotyls. J. Plant Physiol. 135, 110-113.

59. Mitchell, J.C. and Jordan, W.P. (1974) Allergic contact and dermatitis from the radish Raphanus sativus. Br. J. Dermatol. 91, 183-189.

60. Abdou, I.A., Abou-Zeid, A.A., El-Sherbeeny, M.R., and Abou-El-Gheat, Z.H. (1972) Antimicrobial activities of Allium sativum, Allium cepa, Raphanus sativus, Capsicum frutescens, Eruca sativa, Allium kurrat on bacteria. Qual. Plant. Mater. Veg. 22, 29-35.

61. De Samblanx, G.W., Fernandez, C., Sijtsma, J., Plasman, H.H., Schaaper, W.M., Posthuma, G.A., Fant, F., Meloen, R.H., Broekaert, W.F., and van Amerongen, A. (1996) Antifungal activity of synthetic 15-mer peptides based on the Rs-AFP2 (Raphanus sativus antifungal protein 2) sequence. Pept. Res. 9, 262-268.

62. Terras, F.R., Eggermont, K., Kovaleva, V., Raikhel, N.V., Osborn, R.W., Kester, A., Rees, S.B., Torrekens, S., Van Leuven, F., and Vanderleyden, J. (1995) Small cysteine-rich antifungal proteins from radish: their role in host defence. Plant Cell. 7, 573-588.

63. Jong-Heum, P., Heuyn-Kil, S., and Cher-Won, H. (2001) New antimicrobial activity from Korean radish seeds (Raphanus sativus L.) J. Microbiol. Biotechnol. 11, 337-341.

64. Takasugi, M., Monde, K., Katsui, N., and Shirata, A. (1987) Spirobrassinin, a novel sulfur-containing phytoalexin from the daikon Rhaphanus sativus L. var. Hortensis (Cruciferae). Chem. Lett. 1631-1632.

65. Smolinska, U. and Horbowicz, M. (1999) Fungicidal activity of volatiles from selected cruciferous plants against resting propagules of soil-borne fungal pathogens. J. Phytopathol. 147, 119-124.

66. Xiaoling, L., Dongxu, C., Zesheng, Z., and Zhonghua, L. (2001) Study on antioxidative function of red radish pigment. Shipin Kexue 22, 19-21.

67. Akihiro, M., Koji, K., Hiroyoshi, O., Kazuaki, K., and Yoshiko, A. (1999) Antitumor substances from vegetables, their manufacture, and pharmaceutical compositions. Jpn. Kokai Tokkyo Koho JP 11 49,793[99 49,793] (Cl. C07G17/00), 23 feb 1999, Appl. 97/215224, 8 aug 1997.

68. Hasegawa, K., Noguchi, H., Iwagawa, T., and Hase, T. (1986) Phototropism in hypocotyls of radish. Plant Physiol. 81, 976-979.

69. Yasujiro, M., Hayashi, K., Nakagawa, Y., Fumihikino, H., Koji. U., and Toshihiko, O. (2000) Antiplatelet and anticancer isothiocyanates in Japanese domestic horseradish, wasabi. Biofactors 13, 271-273.

70. Yoichi, T., Kazuo, N., Yohichi, H., and Shigeru, Y. (1984) Immunological properties of arabinogalactan proteins (AGPs) from leaves of Cruciferous plants. Agric. Biol. Chem. 48, 2915-2917.

71. Yoichi, T., Kiyoshi, O., Yohichi, H., Harutaka, M, and Shigeru, Y. (1988) Arabinogalactan-proteins from primary and mature roots of radish (Raphanus sativus). Plant Physiol. 86, 155-160.

72. Friis, P. and Kjaer, A. (1966) 4-Methylthio-3-butenyl-isothiocyanate, the pungent principle of radish root. Acta Chem. Scand. 20, 698-705. 
73. Hiroki, M., Asaka, T., Kenji, Y., and Yasushi, U. (1997) Antimicrobial action of 2-thioxo-3-pyrrolidinecarbaldehyde, a major thiolactam compound generated from the pungent principle of radish in an aqueous medium. Food Sci. Technol. Int. Tokyo 3, 353-356.

74. Yong, J.K., Kug, C.Y., Min, K.H., and Kyu, C.B. (2000) Radish extract stimulates motility of the intestine via the muscarinic receptors. J. Pharm. Pharmacol. 52, 1031-1036.

75. Jin, A.S. and Kyung, K.M. (2001) Effect of dry powders, ethanol extracts and juices of radish and onion on lipid metabolism and antioxidative capacity in rats. Han'guk Yongyanghak Hoeji 34, 513-524.

76. Harborne, J.B. and Baxter, H. (1993) Phytochemical Dictionary. A Handbook of Bioactive Compounds from Plants. Taylor and Francis, London.

\section{This article should be referenced as follows:}

Pérez Gutiérrez, R.M. and Perez, R.L. (2004) Raphanus sativus (radish): their chemistry and biology. TheScientificWorldJOURNAL 4, 811-837.

\section{Handling Editors:}

Joseph Chamberlain, Principal Editor for Pharmaceutical Sciences and Therapeutic Drug Monitoring - domains of TheScientificWorldJOURNAL. 
TABLE 1

Alkaloids and Nitrogen Compounds Isolated from Radish

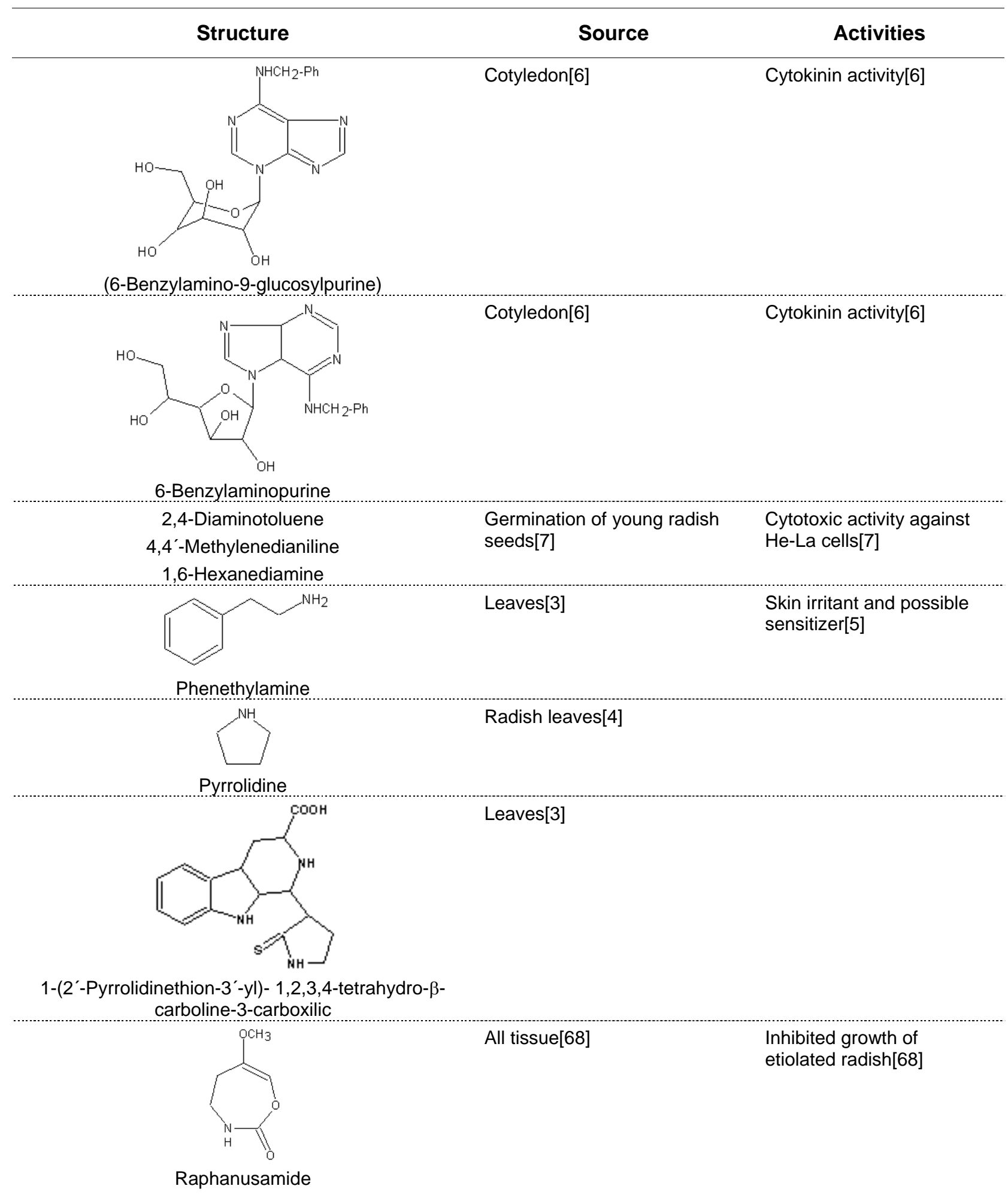


TABLE 1 (CONTINUED)

\section{Alkaloids and Nitrogen Compounds Isolated from Radish}

Source
Activities

TABLE 2

Coumarins Isolated from Radish

\begin{tabular}{ccc}
\hline Structure & Source & Activities \\
\hline Scopoletin & Antifungical[76] & Antispasmodic[76] \\
\hline
\end{tabular}


TABLE 3

Enzymes Isolated from Radish

\begin{tabular}{|c|c|c|}
\hline Structure & Source & Activities \\
\hline Anionic isoperoxidases: $\mathrm{A} 1, \mathrm{~A} 2, \mathrm{~A} 3 \mathrm{n}$, and $\mathrm{A} 3$ & Leaves[29] & \\
\hline$\beta$-Amylase & Roots[23] & \\
\hline Arabinogalactan proteins & $\begin{array}{l}\text { Leaves, primary and mature } \\
\text { roots[10] }\end{array}$ & Serological activity[10] \\
\hline Catalase & Leaves[26] & \\
\hline $\begin{array}{c}\text { Cationic isoperoxidases: } \mathrm{C} 1 \text { and } \mathrm{C} 3 \\
\text { Anionic isoperoxidases: } \mathrm{A} 1, \mathrm{~A} 2, \mathrm{~A} 3 \mathrm{n} \text {, and } \mathrm{A} 3\end{array}$ & Korean radish roots[28]) & \\
\hline Cysteine synthase & Mature roots[21] & Antifungical[21]. \\
\hline$\beta$ - Galactosidase & Seeds[22] & \\
\hline 7-Glucoside de zeatin & Cotyledons[20] & Cytokinin activity[20] \\
\hline$\gamma$-Glutamyl transpeptidase & Bulb[27] & \\
\hline Glutathione reductase & Roots and leaves[27] & $\begin{array}{l}\text { Antioxidant activity; } \\
\text { lowering lipid levels[26] }\end{array}$ \\
\hline Hydroxycinnamoyltransferase & Cotyledons of radish[25] & \\
\hline$\beta$-Fructosidase $(\beta F)$ & Mature leaves[31] & \\
\hline Peroxidase c & Japanese radish roots[24] & \\
\hline Superoxide dismutase & Roots and leaves[75]) & $\begin{array}{l}\text { Antioxidant activity; } \\
\text { lowering lipid levels }\end{array}$ \\
\hline $\begin{array}{l}\text { 1-(Hydroxycinnamoyl)glucose-hydroxyl cinnamoyl- } \\
\text { transferase (CGT) }\end{array}$ & Cotyledons[25] & $\begin{array}{l}\text { Effect on light-grown } \\
\text { seedling[25] }\end{array}$ \\
\hline L-Malate sinapoyltransferase (SMT) & Cotyledons[25] & $\begin{array}{l}\text { Showed effect on light- } \\
\text { grown seedling[25] }\end{array}$ \\
\hline
\end{tabular}

TABLE 4

Gibberellins Isolated from Radish

\begin{tabular}{c} 
Activities \\
\hline
\end{tabular}


TABLE 4 (CONTINUED)

Gibberellins Isolated from Radish

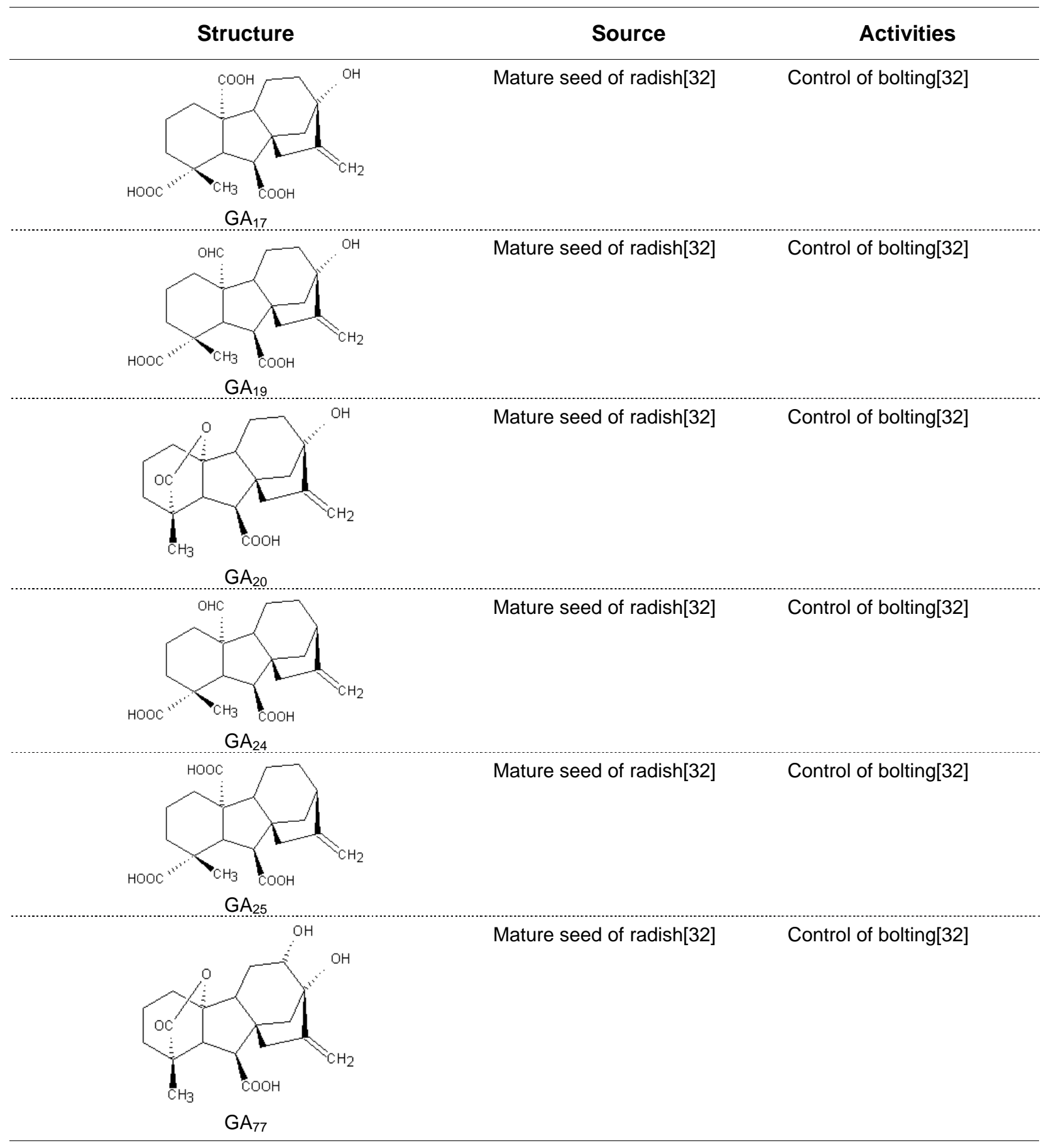


TABLE 5

Organic Acid Isolated from Radish

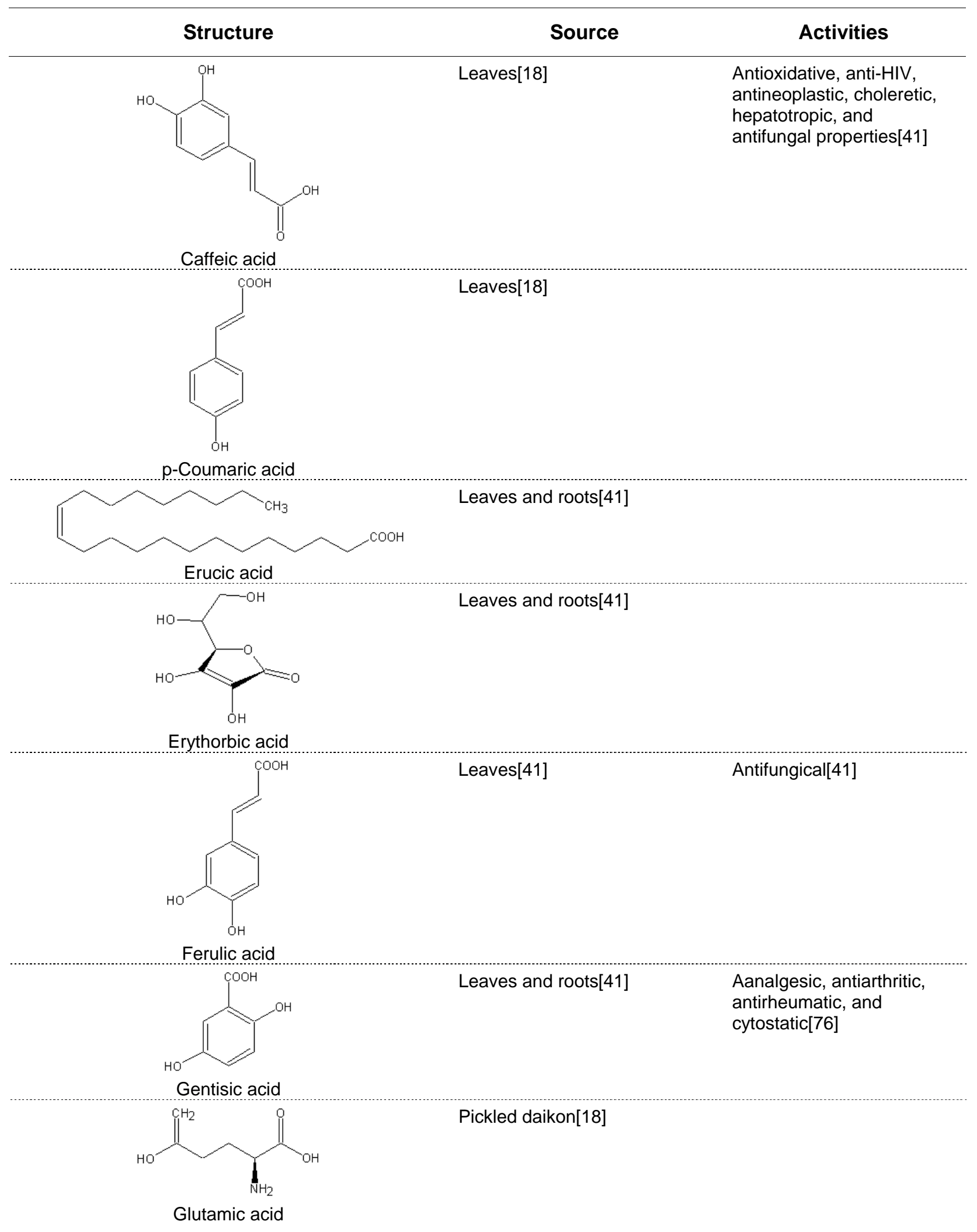


TABLE 5 (CONTINUED)

Organic Acid Isolated from Radish

\begin{tabular}{|c|c|c|}
\hline Structure & Source & Activities \\
\hline $\mathrm{OOH}$ & Leaves and roots[41] & Antimicrobial[76] \\
\hline \multicolumn{3}{|l|}{ Hydrocinnamic acid } \\
\hline & Leaves and roots[18] & Antimicrobial[18] \\
\hline & Leaves and roots[41] & Antifungical[76] \\
\hline & Leaves and roots[41] & Antimicrobial[41] \\
\hline $\begin{array}{l}\text { Linoleic, linolenic, malic, malonic, oleic, oxalic, and } \\
\text { palmitic acid }\end{array}$ & Leaves and roots[39] & \\
\hline
\end{tabular}

TABLE 6

Phenolic Compounds Isolated from Radish

\begin{tabular}{ccc} 
Structure & Source & Activities \\
\hline Cyanidin & Leaves and roots[42] & Antiulcer[76]
\end{tabular}


TABLE 6 (CONTINUED)

Phenolic Compounds Isolated from Radish

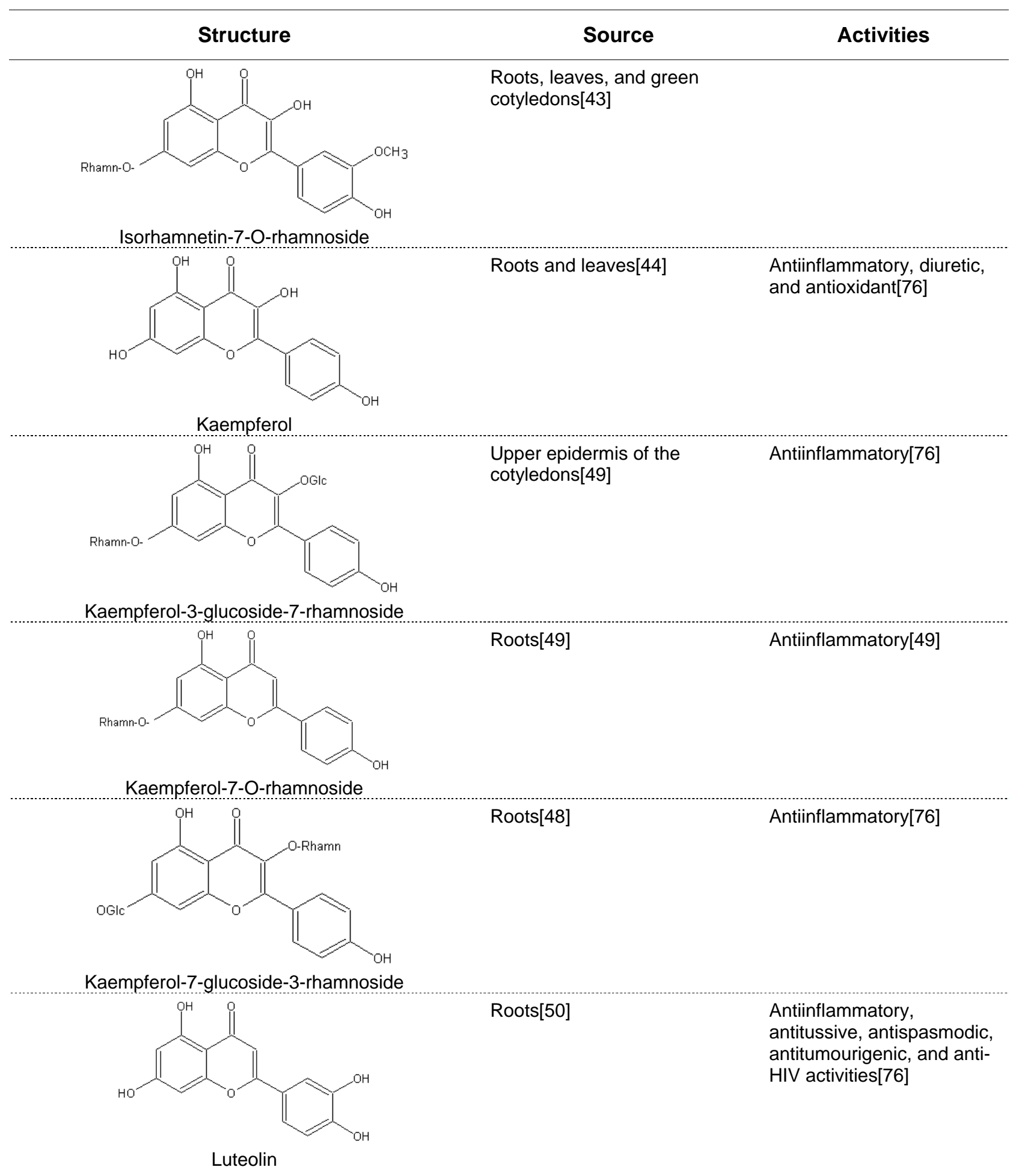


TABLE 6 (CONTINUED)

Phenolic Compounds Isolated from Radish

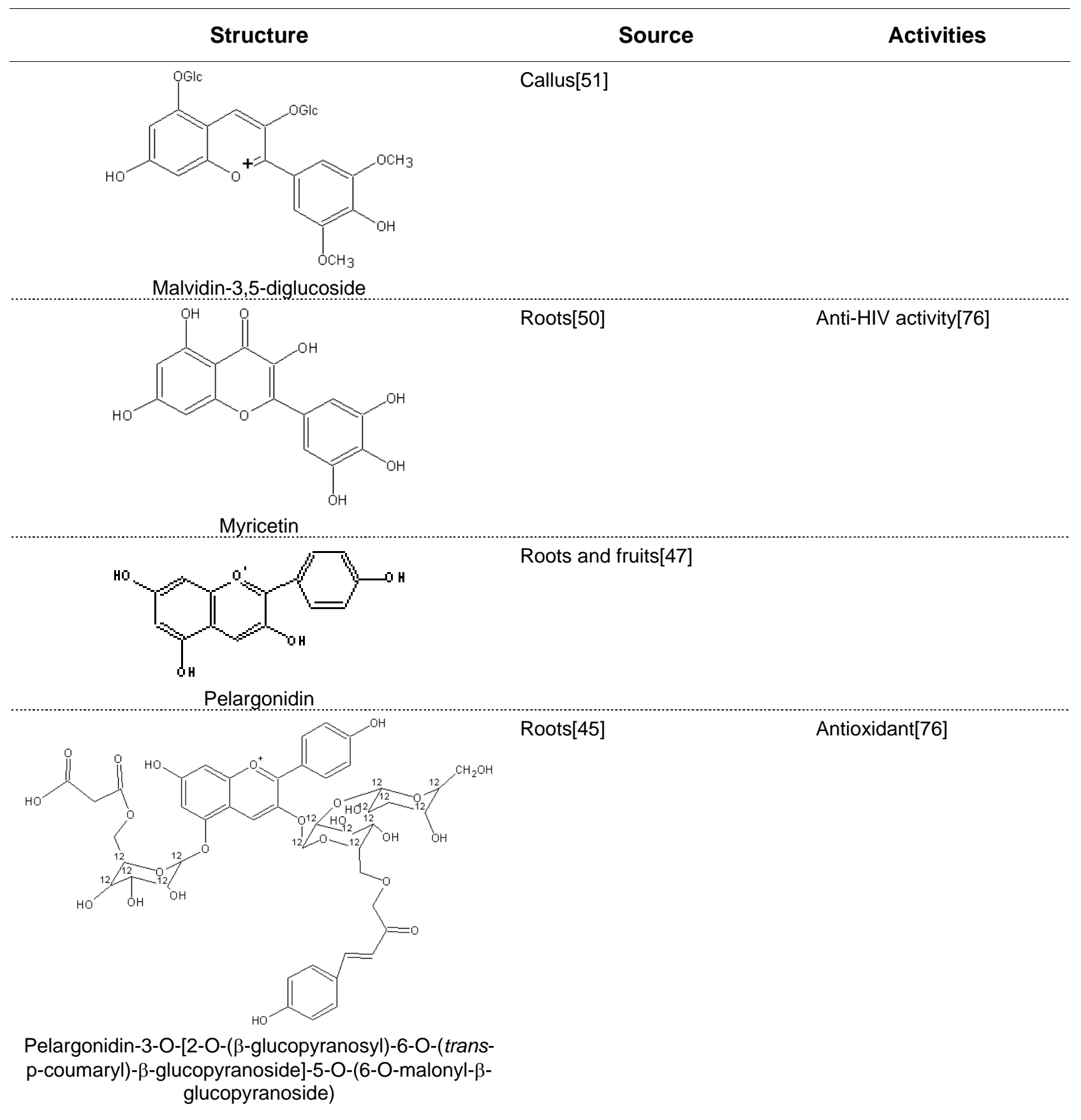


TABLE 6 (CONTINUED)

Phenolic Compounds Isolated from Radish

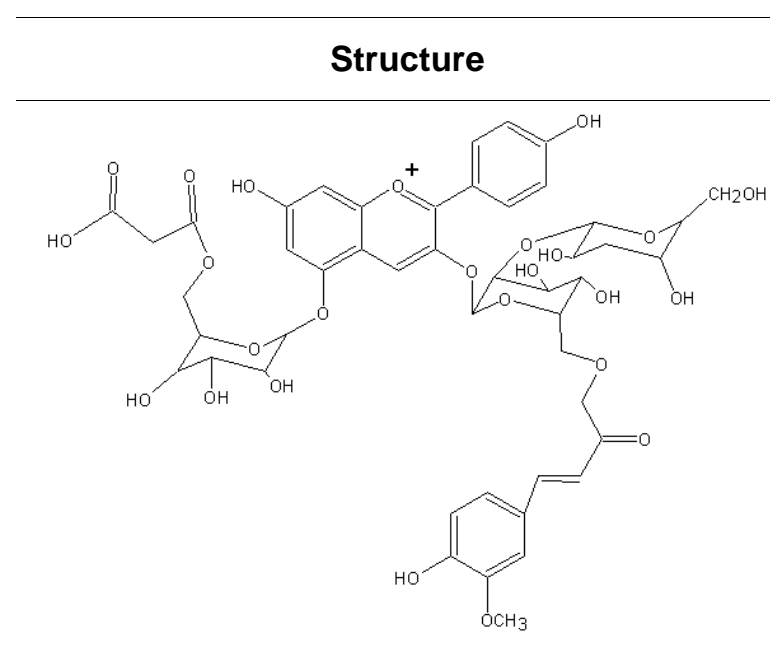

Pelargonidin-3-O-[2-O-( $\beta$-glucopyranosyl)-6-O-(transferuloyl)- $\beta$-glucopyranoside]-5-O-(6-O-malonyl- $\beta$ glucopyranoside)

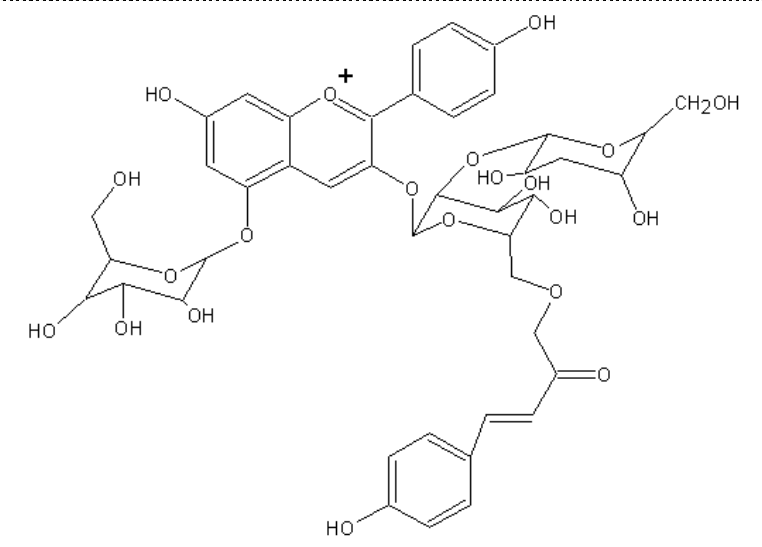

Pelargonidin 3-O-[2-O- $\beta$-glucopyranosyl)-6-O-(transp-coumaroyl)- $\beta$-D-glucopyranoside]-5-O-( $\beta$ glucopyranoside)

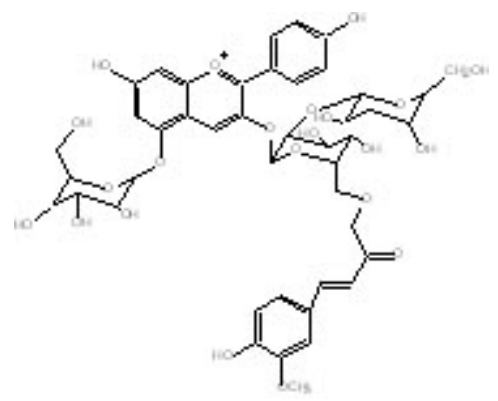

Activities 
TABLE 6 (CONTINUED)

Phenolic Compounds Isolated from Radish

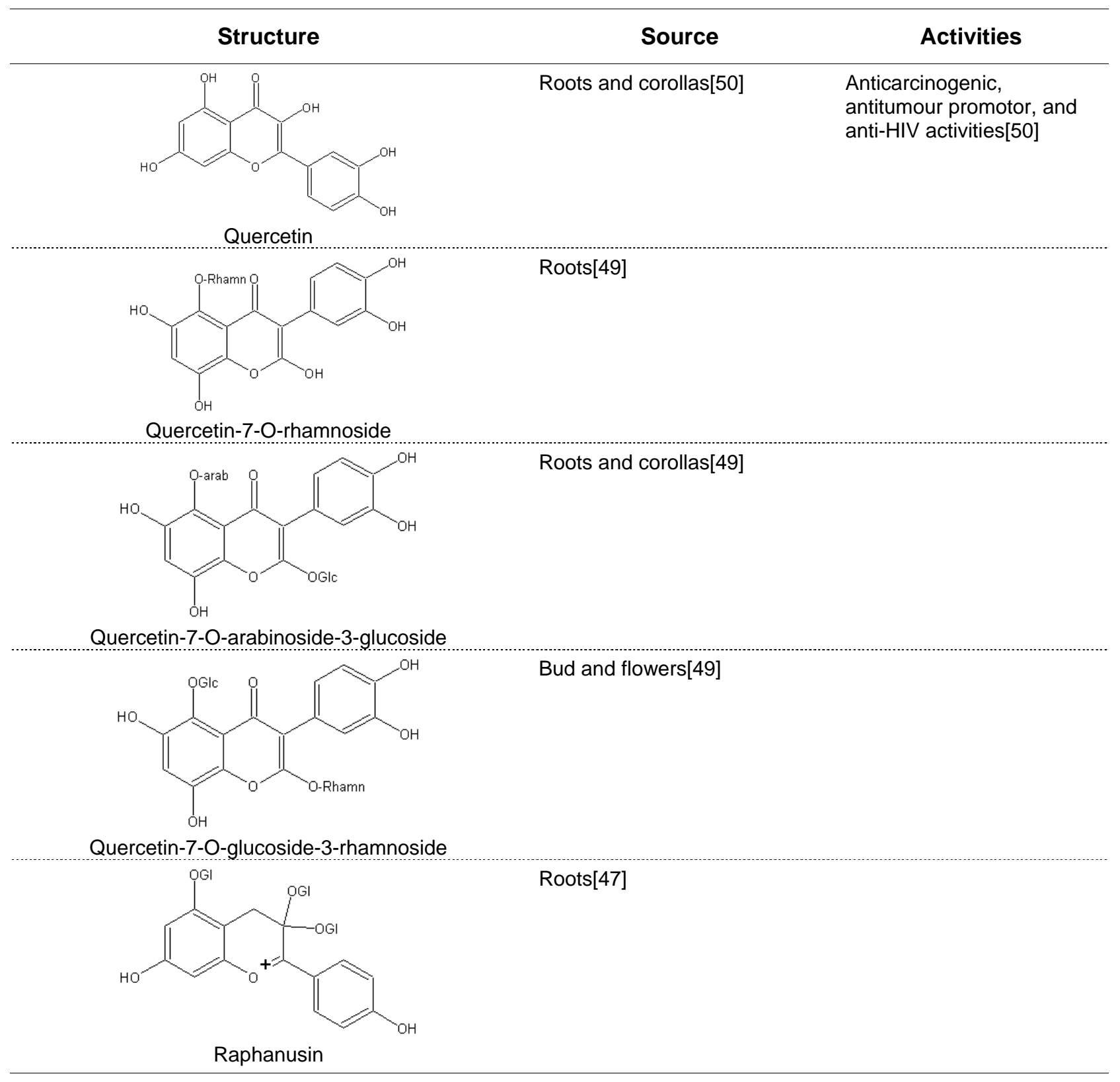


TABLE 7

Polysaccharides Isolated from Radish

\begin{tabular}{ccc}
\hline Structure & Source & Activities \\
\hline Lipopolysaccharides (LPS) & Roots[54] & $\begin{array}{l}\text { Antidiabetic, antiherpes, } \\
\text { analgesic, and having a } \\
\text { macrophage activation[76] }\end{array}$ \\
\hdashline Pectic substances & Leaves[53] & Seeds[55] \\
\hline Proteoglycan & Leaves[53] & \\
\hline Rhamnose, glucose, and xylose & & \\
\hline
\end{tabular}

TABLE 8

Proteins Isolated from Radish

\begin{tabular}{|c|c|c|}
\hline Structure & Source & Activities \\
\hline Arabinogalactan-proteins (AGPs) & Mature leaves[10] & $\begin{array}{l}\text { Reacted with eel anti-H } \\
\text { serum[10] }\end{array}$ \\
\hline $\begin{array}{l}\text { L- Arabino-D-galactan } \\
\text { Arabino-3,6-galactan }\end{array}$ & Mature leaves[11] & $\begin{array}{l}\text { Reacted with eel anti-H } \\
\text { serum[11] }\end{array}$ \\
\hline Chitinase RRC-A & Roots[9] & \\
\hline \multicolumn{3}{|l|}{ Chitinase RRC-B } \\
\hline Cysteine-rich peptides Rs-AFP1 and Rs-AFP2 & Roots[17] & Antimicrobial[17] \\
\hline Ferredoxin isoproteins & Leaves and roots[14] & \\
\hline S-Glycoproteins & Mature leaves[13] & \\
\hline Myrosinase & Daikon[8] & \\
\hline Polypeptides RCA1, RCA2, and RCA3 & Mature leaves[15] & Calmodulin antagonist[15] \\
\hline Proteins AGPs & Mature leaves[10] & $\begin{array}{l}\text { Serological H-like } \\
\text { activity[10] }\end{array}$ \\
\hline Proteins RAP-1 and RAP-2 & Seeds $[63]$ & Antimicrobial[63] \\
\hline Protein AFP1 & Seeds[17] & Antifungical[17] \\
\hline
\end{tabular}

TABLE 9

Sulfur Isolated from Radish

\begin{tabular}{ccc} 
Structure & Source & Activities \\
\hline & Leaves[59] & $\begin{array}{l}\text { Produce allergic contact } \\
\text { and dermatitis[59] }\end{array}$ \\
\hline
\end{tabular}


TABLE 9 (CONTINUED)

Sulfur Isolated from Radish

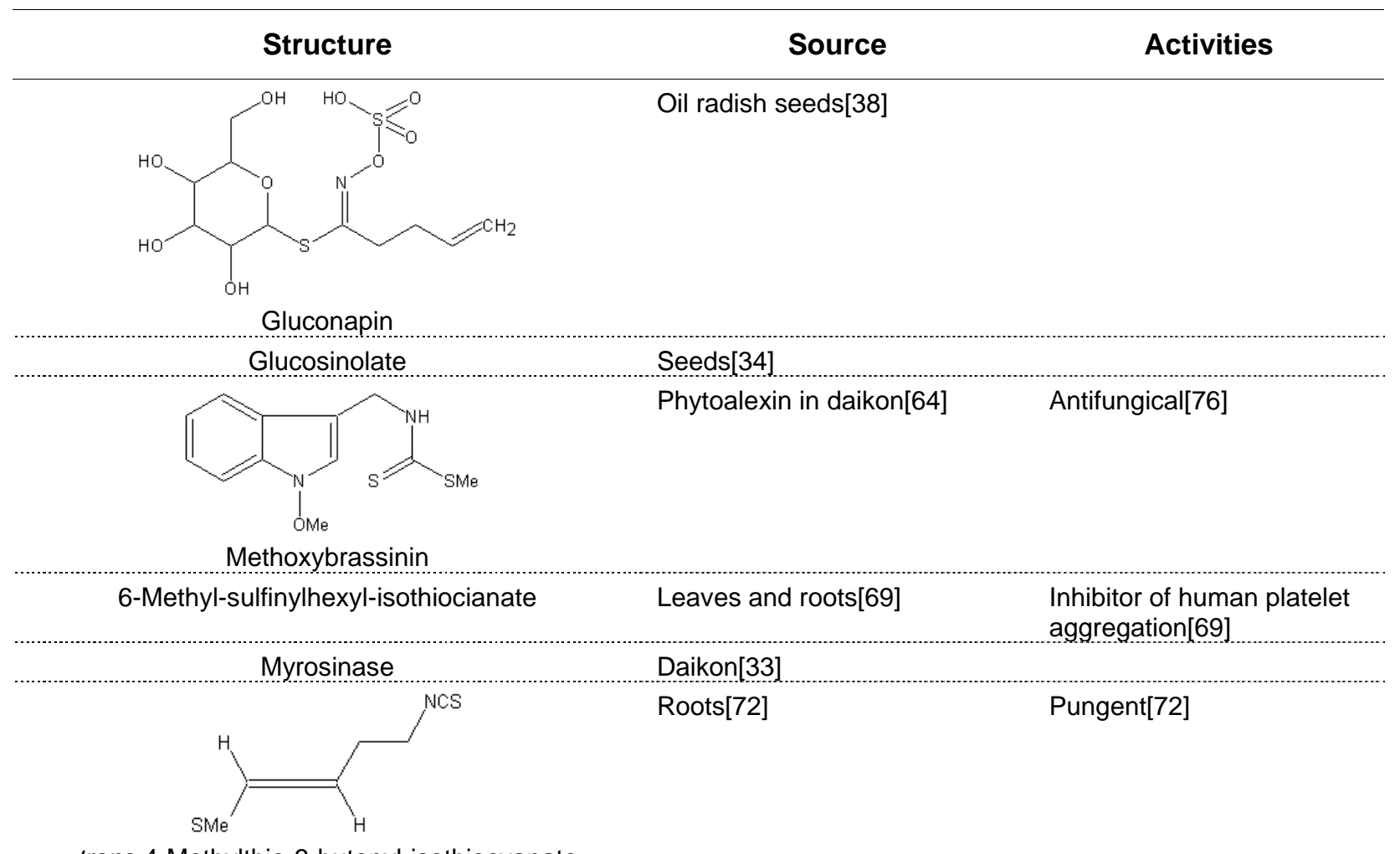

trans-4-Methylthio-3-butenyl-isothiocyanate

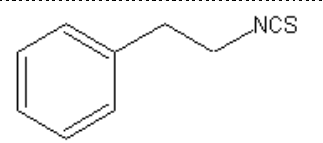

Roots[56]

Phenethylisothiocyanate

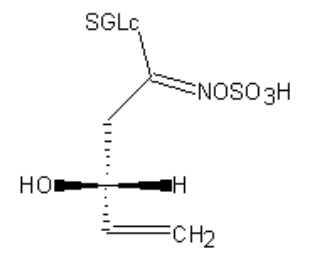

Oil radish seeds[38]

Progoitrin<smiles>O=C(O)C1CC2=C(Nc3ccccc3C2)C(C2CCNC2=S)N1</smiles>

Root[35]

1-(2'-Pyrrolidinethion-3'-yl)-1,2,3,4-tetrahydro- $\beta$ carboline-3-carboxilic acid 
TABLE 9 (CONTINUED)

Sulfur Isolated from Radish

\begin{tabular}{|c|c|c|}
\hline Structure & Source & Activities \\
\hline trans-Raphanusanin & Oil radish seeds[34] & \\
\hline $\begin{array}{c}\mathrm{CH}_{2}=\mathrm{CHCH}_{2} \mathrm{CH}_{2} \mathrm{C}(\mathrm{SGLC})=\mathrm{NOSO}_{3} \mathrm{H} \\
\text { Sinigrin }\end{array}$ & Leaves[33] & $\begin{array}{l}\text { Produce allergic contact } \\
\text { and dermatitis[33] }\end{array}$ \\
\hline hin & Phytoalexin in daikon[64] & Antifungical[76] \\
\hline (S)-sulfonium form of S-adenosylmethion & Immature leaves[56] & \\
\hline 2-thioxothiazolidine-4-carboxilic acid & Roots[61] & $\begin{array}{l}\text { Antimicrobial, inhibited the } \\
\text { growth of hypocotyls[61] }\end{array}$ \\
\hline 5-Vinyl-2-oxazolidinethione & Immature leaves[61] & \\
\hline $\begin{array}{c}\text { Other sulfurs: } \\
\text { Isothiocyanate } \\
\text { Dimethyl disulfide } \\
\text { Methyl methanethiolsulfinate } \\
\text { 1-Methylthio-3-pentanone }\end{array}$ & Oil radish seeds[38] & $\begin{array}{l}\text { Biocidal and fungicidal } \\
\text { activity[38] }\end{array}$ \\
\hline
\end{tabular}


TABLE 10

Other Compounds Isolated from Radish

\begin{tabular}{|c|c|c|}
\hline Structure & Source & Activities \\
\hline Carotenoids & Leaves[57] & Antioxidant[76] \\
\hline Fatty acids & Seeds[8] & \\
\hline & Leaves[68] & Growth inhibitor [68 \\
\hline Raphanusol A & & \\
\hline & Leaves[68] & Growth inhibitor[68 \\
\hline Pentyl & Oil radish seeds[37] & \\
\hline Hexyl & & \\
\hline 4-Methylpentyl & & \\
\hline
\end{tabular}



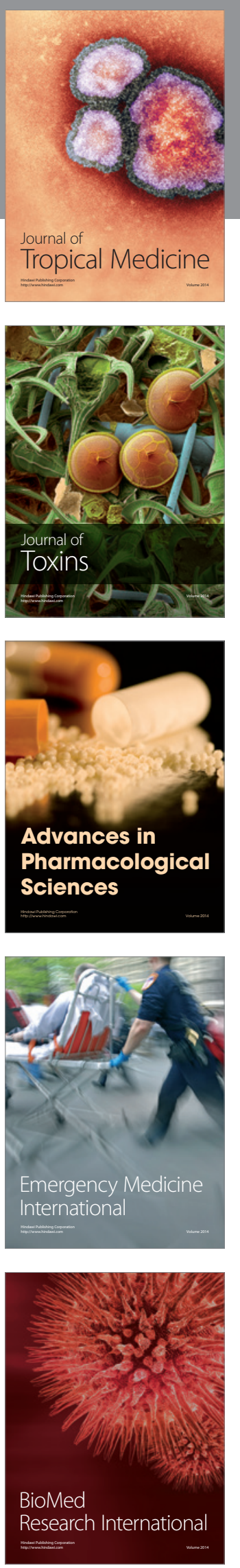
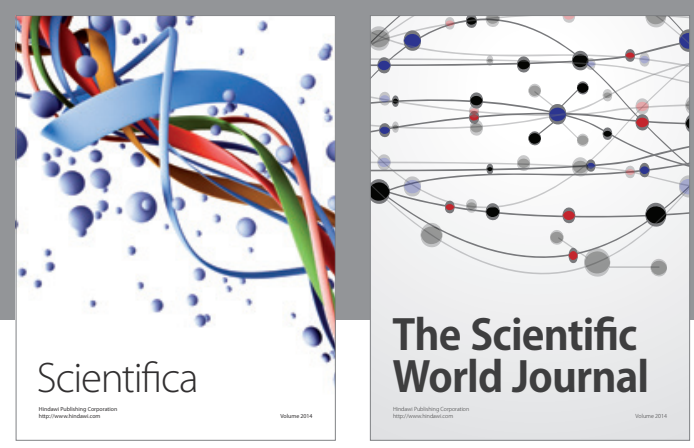

The Scientific World Journal
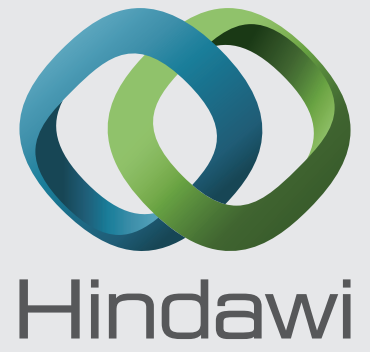

Submit your manuscripts at

http://www.hindawi.com
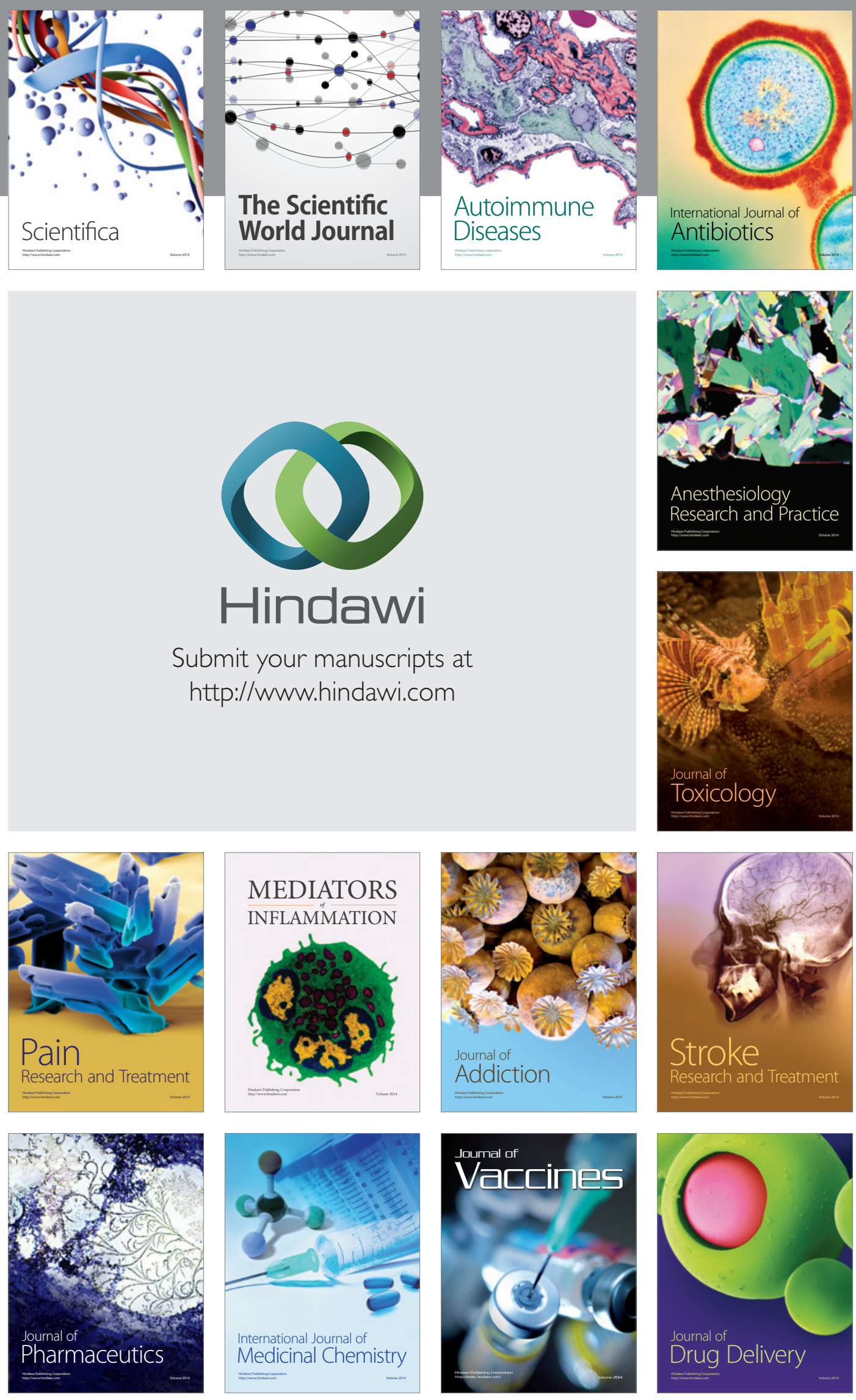